CASE REPORT

\title{
Granular cell tumour of the tongue in a 17-year-old orthodontic patient: a case report
}

\author{
P. Hita-Davis ${ }^{1}$, P. Edwards ${ }^{2}$, S. Conley ${ }^{3}$ \& T.J. Dyer ${ }^{4}$ \\ ${ }^{1}$ Oral Maxillofacial Surgery, School of Dentistry, Ann Arbor, MI, USA \\ ${ }^{2}$ Department of Oral Pathology, Medicine and Radiology, Indiana University, Indianapolis, IN, USA \\ ${ }^{3}$ Department of Orthodontics and Pediatric Dentistry, University of Michigan, Ann Arbor, MI, USA \\ ${ }^{4}$ Oral Surgery, Boston University, Boston, MA, USA
}

\author{
Key words: \\ cyst, diagnosis, examination \\ Correspondence to: \\ DrP Hita-Davis \\ Oral Maxillofacial Surgery \\ School of Dentistry \\ 1011 N. University Avenue \\ Ann Arbor, MI 48109 \\ USA \\ Tel.: +1 7347641542 \\ Fax: +1 7346158399 \\ email: pilarh.davis@yahoo.com
}

Accepted: 6 June 2013

doi:10.1111/ors.12055

\begin{abstract}
To describe the clinical presentation of a granular cell tumour (GCT) in an orthodontic patient, as well as discuss its aetiology and treatment of choice. We present a case of GCT of the tongue in an otherwise healthy 17-year-old male patient along with a brief review of literature on GCTs. The lesion was surgically excised and orthodontic treatment was successfully finalised. Clinically, GCTs are indistinguishable from other benign connective tissue and neural tissue neoplasms and may be found in any site, with cases commonly involving the gastrointestinal system, breast and lung. However, over $50 \%$ of cases involve the head and neck, with the tongue being the most frequently involved site $(65-85 \%$ of oral GCTs). GCTs demonstrate a close anatomical relationship with peripheral nerve fibres and demonstrate the presence of myelin and axon-like structures thus lending credence to their neural origin. The treatment of choice for GCTs is conservative surgical excision. Because GCTs present with a potential for recurrence, follow-up is recommended. While the primary focus of orthodontic treatment is the position of the teeth within the orofacial complex, the health and wellness of the patient and his/her surrounding oral tissues always take precedence. This case demonstrates the importance of routine physical examination of the intraoral and extraoral tissues during routine orthodontic care.
\end{abstract}

\section{Introduction}

In 2011, Moffitt published an investigation of the incidence of pathology noted in the process of obtaining routine 'new patient' diagnostic radiographs ${ }^{1}$. While the incidence of significant pathology in this generally healthy, mostly adolescent, age group was quite small $(0.02 \%)$, some significant and potentially life-threatening pathologies were observed. This study, while reporting on incidence of radiographic pathology, did not look at the presence of pathology in routine extraoral and intraoral examination. Because the study was survey based, it is likely that it under- reports the incidence of pathology found on routine radiographic assessment. In addition, only the opinion and assessment of the orthodontist was assessed, and neither an oral pathologist nor oral and maxillofacial surgeon, both of whom may be more experienced in evaluating radiographs for pathology, were consulted ${ }^{2}$. A more recent publication evaluated a total of 272 cone beam computed tomography films by oral radiologists found an average of over three incidental findings per film ${ }^{3}$.

The standard of care for every dentist and dental specialist is to assess not only the radiographs that are taken, but also to conduct an oral exam on each new 
patient ${ }^{4}$. Once performed, the exam findings must be reassessed at each subsequent office visit. Because orthodontists see their patients frequently (monthly or alternate months) and generally see a healthy adolescent patient pool, it is possible that over time, the re-examination becomes perfunctory. The following case report illustrates the importance of a thorough assessment as the orthodontist evaluates his or her patients at each visit.

\section{Case report}

A 17-year-old male presented to the clinic with a halfcusp Class II Division II malocclusion. He had a palatally impinging overbite with mild maxillary and mandibular crowding (Fig. 1). The temporomandibular joint exam and range of motion exam were performed with normal results. The intraoral/extraoral examination were also normal.
After discussion of his treatment options, it was decided to perform a non-extraction treatment approach to achieve mild maxillary incisor proclination. The family provided their consent and treatment was initiated.

Following 5 months of Class II correction, the patient called the clinic with a complaint of a swelling involving his tongue. He described what could commonly be expected to be an irritation resulting from the Forsus spring. He was provided an immediate appointment to assess his concern. When he came in for observation, he had a swelling on the right lateral aspect of his tongue. Measurements, photographs and a detailed history were taken. Following the visit, an appointment was made with oral and maxillofacial surgery.

At the oral surgery appointment, the now 20-yearold male presented with a 1-month history of an asymptomatic lesion involving the right lateral margin

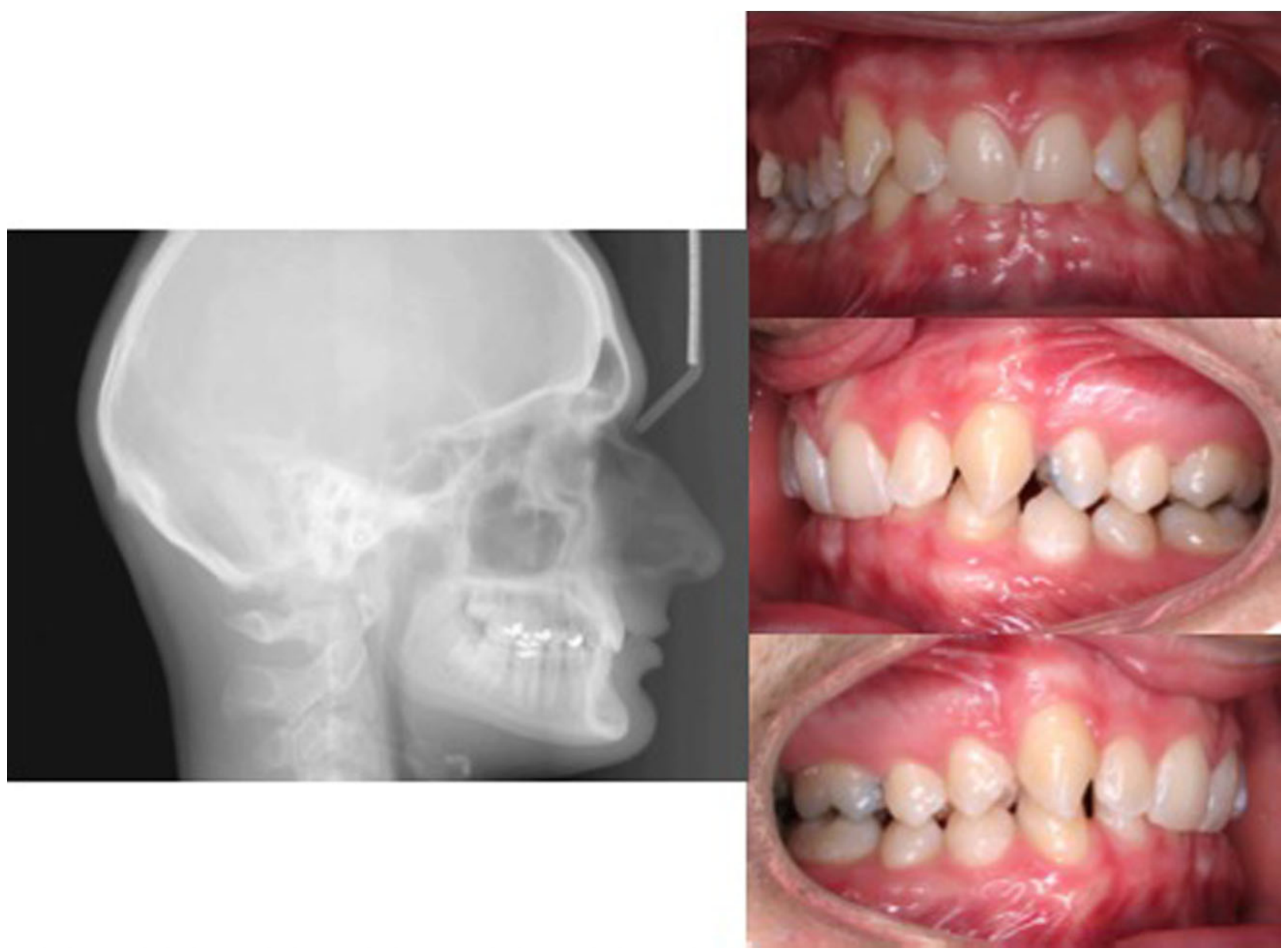

Figure 1 Pretreatment records. The lateral cephalometric radiograph and clinical intraoral photographs depict a 'routine' Class II Division II appearance. The patient has a $100 \%$ overbite and approximately one-half cusp Class II relationship of the buccal segment. 


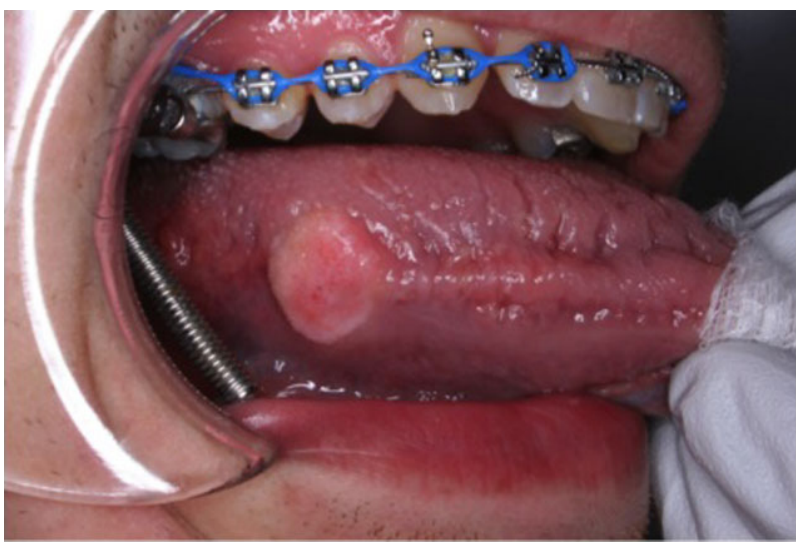

Figure 2 Clinical presentation. A firm light pink submucosal sessile nodule is noted on the right midlateral tongue. Prominent fissuring and a subtle area of benign migratory glossitis are noted anterior to the lesion of interest.

of the tongue (Fig. 2). The patient was 23 months into orthodontic treatment [full fixed edgewise appliances in both arches and Unitek MBT brackets (3M Unitek, Monrovia, CA, USA), along with a fixed functional appliance]. Clinical examination revealed a single, well-circumscribed light pink firm submucosal sessile nodule, measuring $14 \times 13 \mathrm{~mm}$, in a background of bilateral benign migratory glossitis and fissuring. After discussion of the differential diagnosis with the family, an incisional biopsy was recommended. The incisional biopsy revealed the classic histopathological features (Fig. 3) of a granular cell tumour (GCT). One month later after follow-up discussion with the family, definitive excision of the lesion was performed (Fig. 4). Histological examination of the excisional biopsy confirmed the initial diagnosis of GCT.

Following the removal of the GCT, the patient was referred back to the orthodontic clinic for completion of his case. The final occlusal result was excellent demonstrating a Class I molar and canine relationship with ideal overbite and overjet (Fig. 5). The patient's recovery from the surgical procedure was uneventful and satisfactory.

\section{Discussion}

GCTs are relatively uncommon benign neoplasms, first described by Abrikossoff in 1926. This lesion has also been referenced in the literature as Abrikossoff's tumour, granular cell myoblastoma, granular cell neurofibroma and granular cell schwannoma. GCTs may be found in any site, with cases commonly involving the gastrointestinal system, breast and lung. However, over $50 \%$ of cases involve the head and neck. In this area, the tongue is the most frequently involved site accounting for $65-85 \%$ of oral GCTs ${ }^{5-23}$. The larynx and lip are the next most commonly affected sites ${ }^{10}$. Other less frequent intraoral locations include the hard palate, buccal mucosa and gingiva. GCTs have also been reported in the parotid gland.

GCTs typically occur in the fourth to sixth decades of life, although cases have been reported in all age groups, ranging from 11 months to 85 years. GCTs are rare in children. The literature indicates a female predilection for GCTs with a 2:1 predominance ${ }^{7,10,11,13,18,21-23}$.

GCTs lack encapsulation and tend to extend to the underlying skeletal muscle and peripheral nerve. Clinically, GCTs classically present as benign-appearing, slow-growing, solitary, firm white, pink, or yellowish painless submucosal nodules with a smooth or ulcerated surface. They are rarely larger than $3 \mathrm{~cm}^{24-26}$. In 5-15\% of cases, they may present as multiple nodules. However, multiple lesions mostly occur in the intradermal and subcutaneous tissue, although rare cases have been documented in the oral mucosa as well ${ }^{6,7,27-38}$.

Approximately $2 \%$ are classified as malignant based on histopathological presentation. These characteristically present as locally aggressive lesions with distant involvement $t^{6,727-38}$. Indicators of malignancy include areas of necrosis, haemorrhage, size greater than $4 \mathrm{~cm}$, a high mitotic index, cellular atypia and identification of distant metastasis ${ }^{10-13,27,29,35,39-41}$.

At present, the histogenesis of the GCT remains somewhat uncertain ${ }^{5,12,15,18,23,29,30,42-47}$. While originally hypothesised by Abrikosoff to be of muscular origin because of its intimate association with surrounding muscle fibres, the current literature favours neural origin because of strong positive immunohistochemical staining for neural markers such as S-100 protein and neuron-specific enolase ${ }^{10,23,29,30,45-47}$. GCTs demonstrate a close anatomical relationship with peripheral nerve fibres and demonstrate the presence of myelin figures and axon-like structures ultrastructurally, further lending credence to neural origin.

Histologically, GCTs stain intensely eosinophilic and are composed of sheets and nests of large, oval or polygonal cells with abundant granular cytoplasm and small round nuclei that tend to be located centrally. The granular cells often appear intimately associated with muscle and nerve bundles, appearing to emanate from them. Mitotic figures are rarely found. Pseudoepitheliomatous hyperplasia has been reported in the overlying epithelium in up to $87 \%$ of cases ${ }^{23,27,48}$. This benign epithelial reaction often mimics the appearance of squamous cell carcinoma and may result in a misdiagnosis, especially when examining 


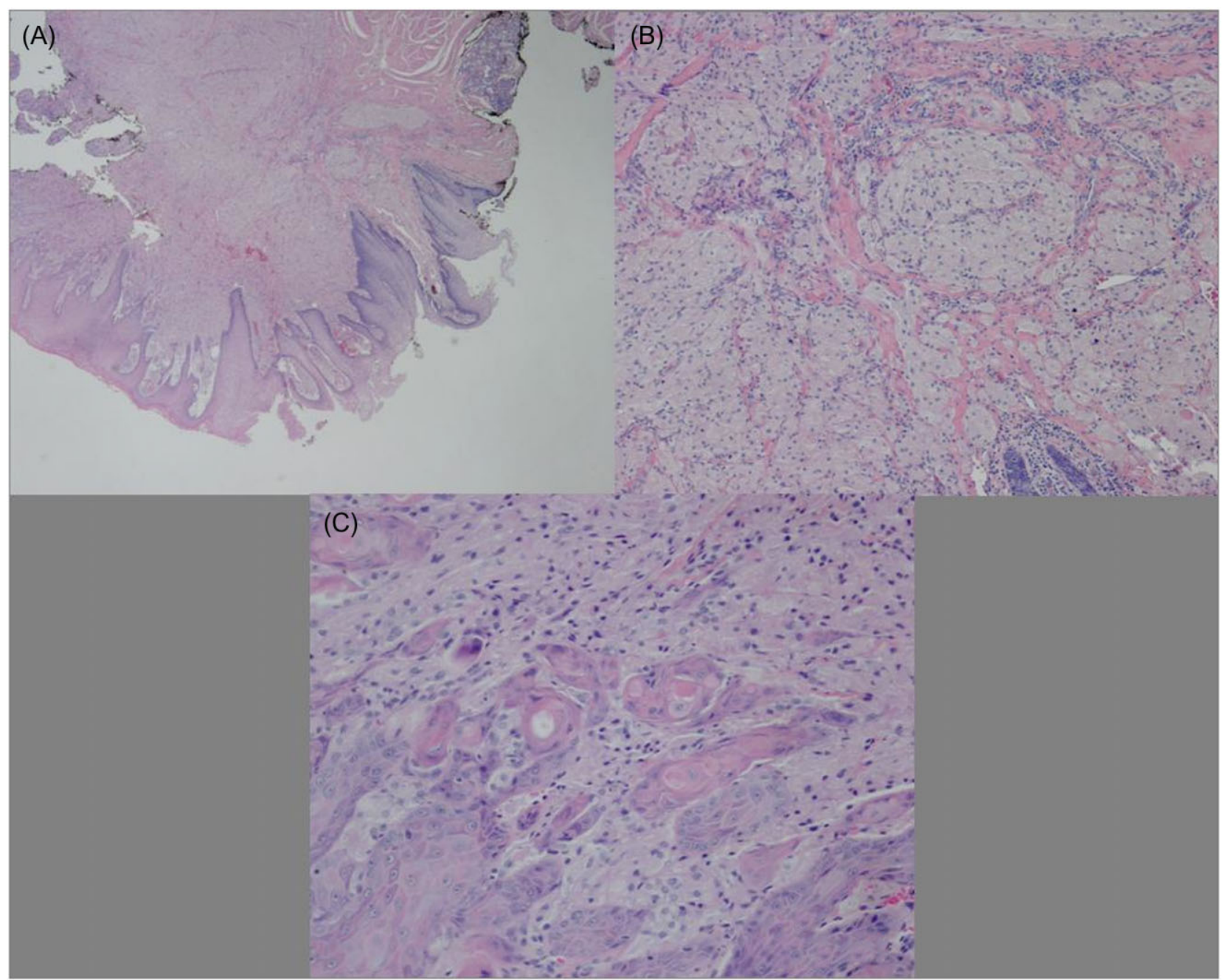

Figure 3 On incisional biopsy, the specimen was noted to consist of a nodule of mucosa surfaced by parakeratinised stratified squamous epithelium (A) demonstrating pseudoepitheliomatous hyperplasia (B) overlying a benign proliferation of large polygonal cells with abundant pale granular eosinophilic cytoplasm (C). The cells are arranged in sheets, nests and cords.

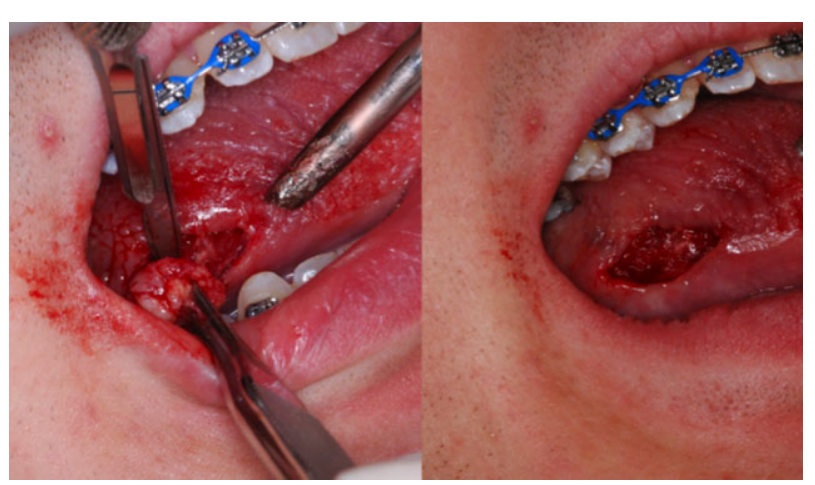

Figure 4 Clinical details of the excisional biopsy. superficial biopsies. For this reason, a biopsy of sufficient depth to reach the underlying granular cells is essential to avoid a potential misdiagnosis.

Clinically, GCTs are indistinguishable from other benign connective tissue and neural tissue neoplasms. As such, the differential diagnosis typically include fibroma, lipoma, schwannoma, neuroma and neurofibroma ${ }^{48}$.

The treatment of choice for GCTs is conservative surgical excision $23,27,30,36,38,48$. Conservative resection of GCTs favours a relatively low recurrence rate of less than $5-10 \%$, with recurrence of the lesion linked to incomplete removal ${ }^{24,48,49}$. Because of the poorly defined margins of a GCT, surgical margins should be completely into the adjacent tissue to ensure complete 


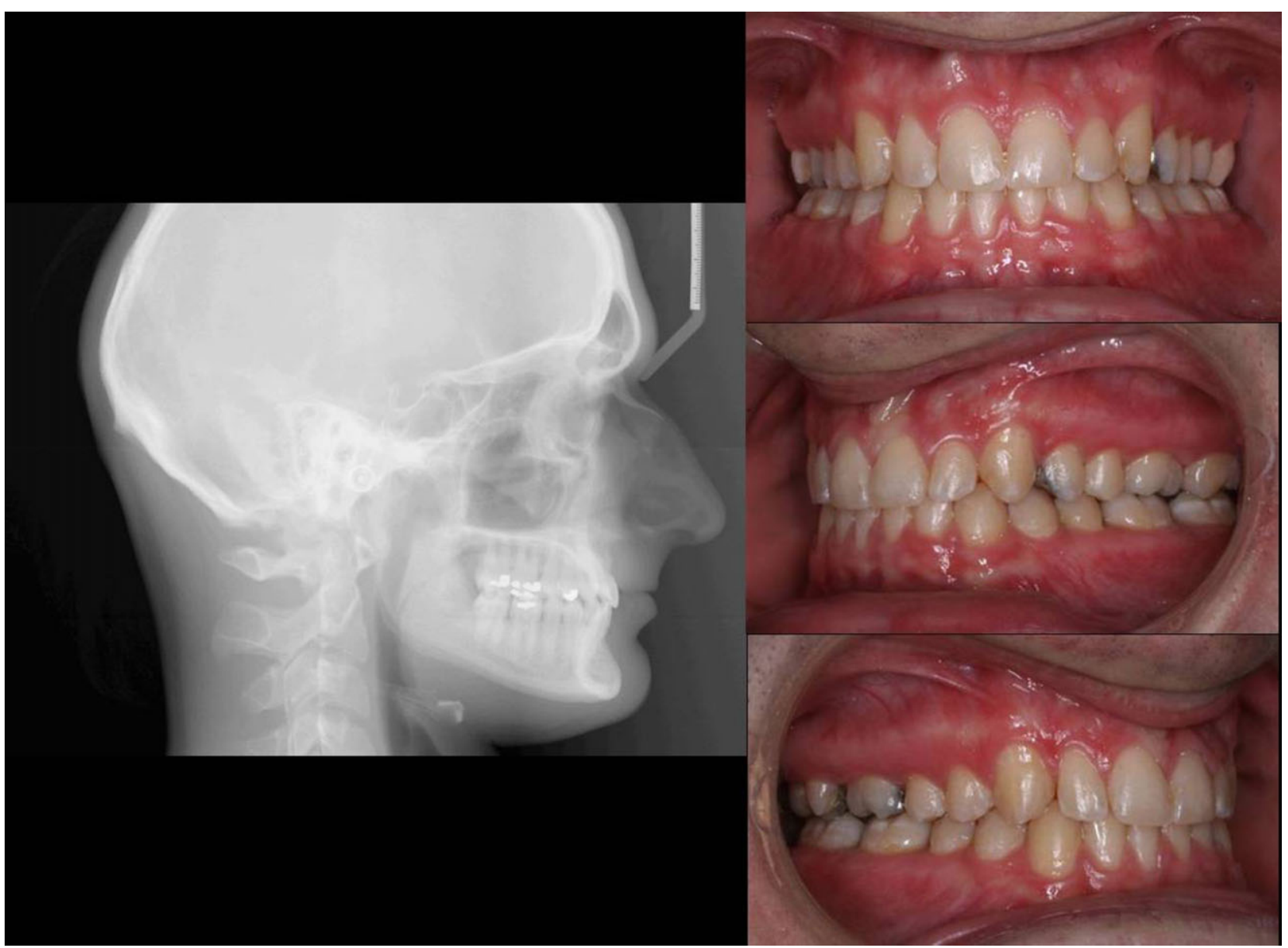

Figure 5 Post-treatment records. The lateral cephalometric radiograph and clinical intraoral photographs depict a properly treated Class I molar and canine relationship. The overbite has been reduced and the patient has a well interdigitated posterior occlusion.

tumour removal. GCTs present with a potential for recurrence; thus, follow-up is recommended ${ }^{30}$.

\section{Conclusion}

While the primary focus of orthodontic treatment is the position of the teeth within the orofacial complex, the health and wellness of the patient always take precedence. This case demonstrates the importance of routine physical examination of the intraoral and extraoral tissues during routine orthodontic care.

\section{References}

1. Moffitt AH. Discovery of pathologies by orthodontists on lateral cephalograms. Angle Orthod 201 1;81:58-63.

2. Ahmed F, Brooks SL, Kapila SD. Efficacy of identifying maxillofacial lesions in cone-beam computed tomographs by orthodontists and orthodontic residents with third-party software. Am J Orthod Dentofacial Orthop 2012;141:451-9.
3. Price JB, Thaw KL, Tyndall DA, Ludlow JB, Padilla RJ. Incidental findings from cone beam computed tomography of the maxillofacial region: a descriptive retrospective study. Clin Oral Impl Res $2011 ; 23: 1-8$.

4. Ellek DM. The ADA's practice parameters. J Am Coll Dent 2005;72:23-7.

5. Williams HK, Williams DM. Oral granular cell tumours: a histological and immunocytochemical study. J Oral Pathol Med 1997;26:64-169.

6. Becelli R, Perugini M, Gasparini G, Cassoni A, Fabiani F. Abrikossoff's tumor. J Craniofac Surg 2001;12:7881.

7. Brannon RB, Anand PM. Oral granular cell tumors: an analysis of 10 new pediatric and adolescent cases and a review of the literature. J Clin Pediatr Dent 2004; 29:69-74.

8. Dunlap CL, Barker BF. Diagnostic problems in oral pathology. Semin Diagn Pathol 1985;2:16-30.

9. Fliss DM, Puterman M, Zirkin H, Leiberman A. Granular cell lesions in head and neck: a clinicopathological study. J Surg Oncol 1989;42:154-60. 
10. Carinci F, Piatelli A, Rubini C, Fioroni M, Stabellini G, Palmieri A etal. Genetic profiling of granular cell myoblastoma. J Craniofac Surg 2004; 15:824-34.

11. Alessi DV, Zimmerman MC. Granular cell tumors of the head and neck. Laryngoscope 1988;98:810-4.

12. Regezi JA, Batsakis JG, Courtney RM. Granular cell tumors of the head and neck. J Oral Surg 1979;37: 402-6.

13. Stefansson K, Wollmann RL. S-100 protein in granular cell tumors (granular cell myoblastomas). Cancer 1982;49:1834-8.

14. Strong EW, McDivitt RW, Brasfield RD. Granular cell myoblastoma. Cancer 1970;25:415-22.

15. Basile JR, Woo SB. Polypoid S-100-negative granular cell tumor of the oral cavity: a case report and review of the literature. Oral Surg Oral Med Oral Pathol Oral Radiol Endod 2003;96:70-6.

16. Jones JK, Kuo TT, Griffiths CM, Itharat S. Multiple granular cell tumor. Laryngoscope 1980;90:164651.

17. Ordoñez NG, Mackay B. Granular cell tumor: a review of the pathology and histogenesis. Ultrastructur Pathol 1999;23:207-22.

18. Haikal F, Maceira J, Dias E, Ramos-E-Silva M. Histogenesis of Abrikossoff tumour of the oral cavity. Int J Dent Hyg 2010;8:53-62.

19. Noonan JD, Horton CE, Old WL, Stokes TL. Granular cell myoblastoma of the head and neck: review of the literature and 10 year experience. Am J Surg 1979; 138:611-4.

20. Chaudhry AP, Jacobs MS, SunderRaj M, Yamane GM, Jain R, Scharlock SE. A clinico-pathologic study of 50 adult oral granular cell tumors. J Oral Med 1984;39: 97-103.

21. Stewart CM, Watson RE, Eversole LR, Fischlschweiger W, Leider AS. Oral granular cell tumors: a clinicopathologic and immunocytochemical study. Oral Surg Oral Med Oral Pathol 1988;65:427-35.

22. Mirchandani R, Sciubba JJ, Mir R. Granular cell lesions of the jaws and oral cavity: a clinicopathologic, immunohistochemical, and ultrastructural study. J Oral Maxillofac Surg 1989;47:1248-55.

23. Vered M, Carpenter WM, Buchner A. Granular cell tumor of the oral cavity: updated immunohistochemical profile. J Oral Pathol Med 2009;38:150-9.

24. Fitzhugh V, Manier K, Gurudutt V, Rivera M, Chen H, $\mathrm{Wu}$ M. Fine-needle aspiration biopsy of granular cell tumor of the tongue: a technique for the aspiration of oral lesions. Diagn Cytopathol 2009;37:839-42.

25. Franzen S, Stenkvist B. Diagnosis of granular cell myoblastoma by fine-needle aspiration biopsy. Acta Pathol Microbiol Scand 1968;72:391-5.

26. El Aouni N, Laurent I, Terrier P, Mansouri D, Suciu V, Delaloge $S$ et al. Granular cell tumor of the breast. Diagn Cytopathol 2007;35:725-7.
27. Bomfin LE, Alves Fde A, de Almeida OP, Kowalski LP, Perez DE. Multiple granular cell tumors of the tongue and parotid gland. Oral Surg Oral Med Oral Pathol Oral Radiol Endod 2009;107:e 10-3.

28. Apisarnthanarax P. Granular cell tumour: an analysis of 16 cases and review of the literature. J Am Acad Dermatol 1981;5:171-82.

29. Angiero F, Crippa R, Stefani M. Granular cells tumour in the oral cavity: a report of eleven cases treated with laser surgery. Minerva Stomatol 2006;55:423-30.

30. Rejas R, Campos M, Cortes AR, Pinto DD, Machado de Sousa SC. The neural histogenetic origin of the oral granular cell tumor: an immunohistochemical evidence. Med Oral Patol Cir Bucal 2011;1: e6-10.

31. Fust JA, Custer RP. On the neurogenesis of so-called granular cell myoblastoma. Am J Clin Pathol 1949;19: 522-35.

32. Lack EE, Worsham GF, Callihan MD, Crawford BE, Klappenbach S, Rowden G et al. Granular cell tumor: a clinicopathological study of 110 patients. J Surg Oncol 1980;13:301-16.

33. Kershisinik M, Batasakis J, McKay B. Granular cell tumors. Ann Otol Rhinol Laryngol 1994;103:416-9.

34. Junquera LM, de Vicente JC, Vega JA, Losa JL, Albertos JM, Lopez-Arranz JS. Granular cell tumors: an immunohistochemical study. Br J Oral Maxillofac Surg 1997;35:180-3.

35. Fanburg-Smith JC, Meis-Kindblom JM, Fante R, Kindblom LG. Malignant granular cell tumor of soft tissue: diagnostic criteria and clinicopathologic correlation. Am J Surg Pathol 1998;22:779-94.

36. Billeret-Lebranchu V. Granular cell tumor. Epidemiology of 263 cases. Arch Anat Cytol Pathol 1999;47:2630.

37. Liu K, Madden JF, Olatidoye BA, Dodd LG. Features of benign granular cell tumor on fine needle aspiration. Acta Cytol 1999;43:552-7.

38. Budino-Carbonero S, Navarro-Vergara P, RodriguezRuiz JA, Modelo-Sanchez A, Torres-Garzon L, RendonInfante JI et al. Granular cell tumors: review of the parameters determining possible malignancy. Med Oral 2003;8:294-8.

39. Khansur T, Balducci L, Tavassoli M. Granular cell tumor: clinical spectrum of the benign and malignant entity. Cancer 1987;60:220-2.

40. Klima M, Peters J. Malignant granular cell tumor of soft tissue diagnostic criteria and clinicopathologic correlation. Am J Surg Pathol 1998;22:779-94.

41. Schoedel KE, Bastacky S, Sliverman A. An S100 negative granular cell tumor with malignant potential report of a case. J Am Acad Derm 1998;39:894-8.

42. Fisher ER, Wechsler H. Granular cell myoblastoma - a misnomer. Electron microscopic and histochemical evidence concerning its Schwann cell derivation and 
nature (granular cell schwannoma). Cancer 1962;15: 936-54.

43. Krolls SO, McGinnis JP Jr, Quon D. Multinodular versus plexiform neurilemoma of the hard palate. Report of a case. Oral Surg Oral Med Oral Pathol 1994;77:154-7.

44. Aparicio S, Lumsden C. Light and electron microscopic studies on granular cell myoblastoma of the tongue. J Pathol 1969;97:339-55.

45. Mentzel T, Waden C, Fletcher CD. Granular cell change in smooth muscle tumours of skin and soft tissue. Histopathology 1994;24:223-31.

46. Mahalingam M, LoPiccolo D, Byers HR. Expression of PGP 9.5 in granular sheath tumors: an immunohisto- chemical study of six cases. J Cutan Pathol 2001;28: 282-6.

47. Miettinen M, Lehtonen E, Lehtola H, Ekblom P, Lehto VP, Virtanen O. Histogenesis of granular cell tumour: an immunohistochemical and ultrastructural study. J Pathol 1984;142:221-9.

48. Eguia A, Uribarri A, Gay-Escoda C, Crovetto MA, Martínez-Conde R, Aguirre JM. Granular cell tumor: report of 8 intraoral cases. Med Oral Patol Oral Cir Bucal 2006; 11:E425-428.

49. Giuliani M, Lajolo C, Pagnoni M, Boari A, Zannonni GF. Granular cell tumor of the tongue (Abrikossoff's tumor). A case report and review of the literature. Minerva Stomatol 2004;53:465-9. 